OPEN ACCESS

Edited by:

Wei Wei,

Institute for Systems Biology (ISB),

United States

Reviewed by:

Nicola Elizabeth Annels,

University of Surrey, United Kingdom

Farhad Jadidi-Niaragh,

Tabriz University of Medical Sciences,

Iran

*Correspondence:

Chun Xu

chun.xu@uq.edu.au

Ning Cheng

Ning.Cheng@ucsf.edu

Specialty section: This article was submitted to

Cancer Immunity and Immunotherapy,

a section of the journal

Frontiers in Immunology

Received: 06 September 2021 Accepted: 08 November 2021 Published: 25 November 2021

Citation:

Ye Y, Xu C, Chen F, Liu Q and

Cheng N (2021) Targeting Innate Immunity in Breast Cancer

Therapy: A Narrative Review.

Front. Immunol. 12:771201. doi: 10.3389/fimmu.2021.771201

\section{Targeting Innate Immunity in Breast Cancer Therapy: A Narrative Review}

\author{
Yanqi Ye ${ }^{1}$, Chun $X u^{2 *}$, Fengqian Chen ${ }^{3}$, Qi Liu ${ }^{4}$ and Ning Cheng ${ }^{5 *}$ \\ 1 Zenomics. Inc. Magnify at California NanoSystems Institute, Los Angeles, CA, United States, 2 School of Dentistry, The \\ University of Queensland, Brisbane, QLD, Australia, ${ }^{3}$ School of Medicine, University of Maryland, Baltimore, MD, United \\ States, ${ }^{4}$ School of Medicine, Johns Hopkins University, Baltimore, MD, United States, ${ }^{5}$ Department of Otolaryngology - \\ Head and Neck Surgery, University of California at San Francisco, San Francisco, CA, United States
}

Although breast cancer has been previously considered "cold" tumors, numerous studies are currently conducted to explore the great potentials of immunotherapies in improving breast cancer patient outcomes. In addition to the focus on stimulating adaptive immunity for antitumor responses, growing evidence showed the importance of triggering host innate immunity to eradicate established tumors and/or control tumor metastasis of breast cancer. In this review, we first briefly introduce the breast tumor immune microenvironment. We also discuss innate immune targets and pathways and mechanisms of their synergy with the adaptive antitumor response and other treatment strategies. Lastly, we review clinical trials targeting innate immune pathways for breast cancer therapies.

Keywords: innate immunity, breast cancer, cancer immunotherapy, clinical studies, vaccine adjuvants

\section{INTRODUCTION}

Breast cancer is considered one of the leading causes of death in women. The American Cancer Society (ACS) predicted that nearly 280,000 new breast cancer cases would be diagnosed in 2020 . Over 40,000 breast cancer-related deaths can be present in the same year (1). Breast cancer disease is well known for its phenotypical heterogeneity. It is usually classified into three subtypes that display unique cellular and molecular patterns: luminal ER-positive, HER2-like, and basal-like subtype (2, 3). In general, breast tumors mainly consist of malignant cells, extracellular matrix (ECM), and stromal components, including infiltrating immune cells that shape tumor initiation. The malignant cells undergo a constant evolution during tumor development to form a specialized tissue architecture with a dissociated ECM and cancer-associated inflammation (4).

\section{THE IMPORTANCE OF INNATE IMMUNITY IN BREAST CANCER}

\subsection{Overview of Immunology in Breast Cancer}

Notably, cancer-associated inflammation, including cancer-intrinsic inflammation and cancer extrinsic inflammation, is present at different stages of breast tumorigenesis (5-8). Cancer-intrinsic inflammation is usually triggered by cancer-initiating mutations that are genetically stable and can be predictable for drug treatment response or resistance (7). Leukocytes are recruited and migrated to the cancer site, further undergoing activation during tumor progression. However, cancer-extrinsic inflammation is associated with various exogenous risk factors, such as bacterial or viral infections, 
obesity, excessive alcohol consumption, tobacco smoking, hormone therapies, autoimmune diseases, overexposure to radiation, etc. (8). Both cancer-intrinsic and cancer-extrinsic inflammation contribute reciprocally to immunosuppression, which provides a favorable environment for malignant progression.

\subsection{Breast Cancer Immune Microenvironment}

The microenvironment of breast cancer is highly inflammatory. It consists of a broad spectrum of stromal components, including mesenchymal-derived fibroblasts, pericytes, vascular structure, infiltrating immune cells, cytokines and growth factors, which coordinately enable carcinogenesis and breast tumor progression (9-12). The breast tumor stroma complex also supports neovascularization, as well as functionally modulating the immune cells, cytokines and inflammatory cascade. These together orchestrate the formation of solid breast tumors $(5,13$, 14). Breast tumor microenvironment is populated by diverse innate immune cells (macrophages, dendritic cells, natural killer cells, myeloid-derived suppressor cells, mast cells, and granulocytes) and adaptive immune cells ( $\mathrm{T}$ and B lymphocytes, NKT cells) (Figure 1). These infiltrating immune cells are either originated from residential mammary tissue associated populations or recruited from the periphery or draining lymphoid organs. The types of inflammatory cells and their roles have been well identified in both animal and human breast cancer studies $(6,10,15,16)$. For example, human monocytes/ macrophages have been demonstrated to produce EGF receptor
(EGFR) ligands and stimulate STAT3 signaling pathway to promote mammary tumor cell invasion, which in turn facilitated TAMs infiltration depending on the secreted CSF1 and CXCL12 $(17,18)$. Another study has reported that inflammatory breast cancer patients express a high level of IL8 and growth-regulated oncogene (GRO) chemokines that activate STAT3, which induce the formation of immune-suppressive M2-like macrophages and cancer mesenchymal cells (15). In murine 4T1 metastatic breast tumors, tumor entrained neutrophils have been shown to mediate anti-metastasis in the lung by inducing oxidative stress and CCL2 (19). Furthermore, a cohort study of approximately 3000 patients suggested that circulating leukocyte profiles may serve as biomarkers to predict breast cancer risk (16). Collectively, these innate immune cells can regulate tumor cell invasion, differentiation, and disease development.

Moreover, recent findings suggested that infiltrating immune cells are associated with treatment response, which can potentially predict clinical outcomes in breast cancer patients. For instance, tumor-infiltrating $\mathrm{CD}^{+}$cytotoxic lymphocytes were positively correlated with tumor stage and improved survival rate (20). In contrast, the infiltrating regulatory $\mathrm{T}$ cells correlated with poor treatment outcomes in both ER-negative and positive breast cancers $(21,22)$. In particular, infiltrating innate immune cells build a cellular network and rigorously regulates the antitumor response via direct tumor killing and/or bridging and activating the adaptive antitumor immunity (12, 13). Here, we focus on discussing the innate immune cells and therapeutic targets and pathways for developing translational antitumor treatment.

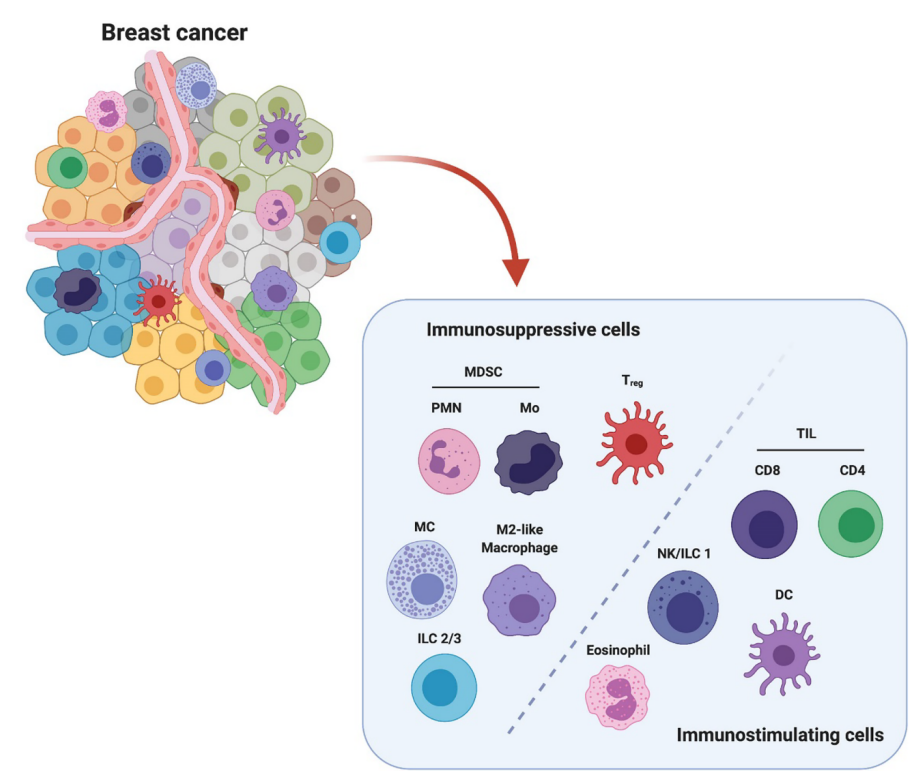

FIGURE 1 | Breast cancer microenvironment is populated by diverse infiltrating immune cells. These immune cells are categorized into immunosuppressive population and immunostimulating population (e.g.) according to their major characteristics in modulating breast cancer. The immunosuppressive cells include polymorphonuclear myeloid-derived suppressor cells (PMN-MDSCs), monocytic MDSC (Mo-MDSC), regulatory T cells (Treg), mast cells (MC), M2-like macrophages and type $2 / 3$ innate lymphoid cells (ILC 2/3). The immunostimulating cells include tumor infiltrating lymphocytes CD8 ${ }^{+}$and CD4 ${ }^{+} \mathrm{T}$ cells, nature killer cells/type 1 innate lymphoid cells (NK/LC1), dendritic cells (DCs) and eosinophils. 


\subsection{Impact of Innate Immunity in Breast Cancer}

Innate immune populations play key roles during cancer evolution, specifically contributing to early responses against cancer-associated inflammation. They also can initiate a complete and vigorous antitumor response via regulating critical pathways for enhanced priming of adaptive immunity. In breast cancer, malignant cells primarily encounter different innate immune cells to trigger specific downstream cascades. Classic activation of adoptive $\mathrm{T}$ cell response needs three signals transmitted from innate antigen-presenting cells (APCs) (23). For instance, professional APCs, including DCs and macrophages, first recognize and bind to the dying breast tumor cells or release tumorassociated antigens through pattern recognition receptors (PRRs) $(24,25)$. PRRs can identify and recognize the damage-associated molecular patterns (DAMPs), which are derived from the tumor or dying cells to drive cancer intrinsic inflammation. They can also detect foreign pathogen-associated molecular patterns (PAMPs), including the microbes encountered during extrinsic cancer inflammation $(24,26)$. Upon binding of DAMPs or PAMPs, APCs internalize and load tumor antigen or DNA into upregulated major histocompatibility complex (MHC). They form MHC-peptide complexes, binding to the $\mathrm{T}$ cell receptor (TCR) as the first activation signal (27). To further activate adaptive lymphocytes for tumor antigen-specific cytotoxic killing, APCs are required to display co-stimulatory molecules of both CD80 and CD86 and recognize the CD28 expressed on lymphocytes as the second signal (28). The secreted cytokines (e.g., TGF- $\beta$, IL-1 $\beta$, IL-6, IL-23, IL-12, and interferon) act as the third signal to support repolarization of the activated lymphocytes into specific subsets, which can induce distinct proinflammatory (antitumoral) or anti-inflammatory (pro-tumoral) responses (29).

Breast cancer, including ER-positive and ER-negative subsets, has heterogeneous patterns of innate immune infiltration. In ERpositive breast tumors, NK cells and neutrophils have been found as major innate immune populations $(9,30)$. Tumor cells are known to escape the host immune attack by self down-regulating MHC Class I antigens, which can be recognized by NK cells and potentially induce antitumor effect via the release of stimulatory cytokines and chemokines (31). Interestingly, the cooperative interplay between NK cells and intratumoral type I conventional dendritic cells ( $\mathrm{cDC1}$ ) can affect tumor microenvironment in response to checkpoint immunotherapy $(32,33)$. Others have reported the use of eosinophils, monocytes, and mast cells as prognostic biomarkers in breast cancer, while tumor-associated macrophages (TAMs) have been associated with poor prognosis (34-37). In ER-negative breast tumors, a large proportion of TAMs and mature mast cells was correlated with an increased risk of metastasis and poor prognosis. Meanwhile, cDC1s responses are significant against breast cancer. Despite their small proportion within breast tumors, cDCs are associated with favorable immune infiltrate and better prognosis $(36,38-$ 40). Recently studies have shown that CDC1 induce antitumor responses by facilitating Th1 immunogenic microenvironment, which correlates with the levels of IL-12, IFN- $\gamma$, and cytotoxic lymphocyte-recruiting chemokines (41-45). These findings suggest the impact of innate immunity in modulating the immunosuppressive microenvironment that can improve breast cancer immunotherapeutic outcomes. Therefore, we believed that explore the defining characteristics of the innate immunity provided a much-needed bridge for translational breast cancer research.

\section{PRECLINICAL STUDIES TARGETING INNATE IMMUNITY FOR BREAST CANCER THERAPY}

Innate immunity is the primary defense line of the host against mammary tumor progression. Upon encountering dying breast tumor cells released components, immune surveillance is established for direct antitumor activities, including immune recognition and suppression $(46,47)$. Specifically, the anticancer innate immune cells participate in releasing cytotoxic contents to directly kill target breast tumor cells, engaging professional antigen-presenting cells to detect and remove breast tumor cells, and further activating the phagocytosis process or alternative complement pathways. Thus, modulating innate immunity paves the way for developing innovative cancer therapeutic interventions in preclinical settings of breast carcinoma.

\subsection{Colony-Stimulating Factors}

Colony-stimulating factors (CSF) are hematopoietic cytokines that regulate the proliferation, maturation, and apoptosis of myeloid cells (48). Based on their origins, CSF can be classified as macrophage CSF (M-CSF), granulocyte CSF (G-CSF), granulocyte-macrophage CSF (GM-CSF), and interleukin-3 (IL-3). In breast cancer, CSFs have been reported to play different roles in various stages of tumor immunity. One recently study has shown that CSFs derived from mammary tumor cells primarily regulate myeloid cell arginase 1 expression and form the immunosuppressive microenvironment while inhibiting host anti-tumor immunity (49). In contrast, others have found that CSFs involved in triggering the antigen presentation in the tumor microenvironment to harness innate immunity for antitumor responses. For example, GM-CSF can recruit DCs to the tumor site and undergo cell proliferation and maturation there, and matured DCs are optimally equipped with antitumor immunity (50). They further infiltrate the tumors to stimulate antigen presentation and activate adaptive immunity (30). GM-CSF has been reported to increase the percentage of DCs in tumor-draining lymph nodes and enhance tumorspecific immunity for treatment (51). GM-CSF secreting tumor cells were modulated as a vaccination approach to completely protect the mice after challenging with live parental breast cancer cells (52).

Furthermore, the abundance of M-CSF1 and its receptor (CSF-1R) expressed on TAMs has been correlated to poor clinical outcomes in breast cancer (53). Consistent with this finding, CSF-1R blockade by using small molecular inhibitors and monoclonal antibodies has been applied to deplete TAMs in breast cancer (54). However, Hollmen et al. discovered that anti- 
CSF-1R treatment could facilitate 4T1 breast tumor cell metastasis to lung and lymph nodes, since 4T1 tumors express high levels of G-CSF (55). Therefore, understanding the sophisticated mechanism of CSF/CSF-1R interaction between tumor and innate immunity can guide to select CSF targeting agents for clinical treatment.

\subsection{Interferons}

Interferons (IFNs), including type I and II IFNs, are involved in regulating immune response in breast cancer. Activation of the type I IFNs (IFN- $\alpha / \beta)$ signaling pathway can cause cancer cell apoptosis and cellular senescence, and breast tumor cell secreted type I IFNs has been shown to induce anti-metastatic response. However, type I IFNs also attributed to drug resistance specifically in triple negative breast cancers (TNBC) and inflammatory breast cancer (IBC) (56, 57). Type II IFNs (IFN- $\gamma$ ), on the other hand, has been reported to cause tissue damage in response to tumor hyperproliferation. The initiation of tissue damage signals, such as IFN- $\gamma$, triggers the innate immune response by recruiting $\mathrm{NK}$ cells and $\mathrm{T}$ helper cells for differentiation (58). Previous studies have reported the essential roles of IFN- $\gamma$ signals in polarizing TAMs phenotypes (59) and modulating the MHC I expression level on breast tumor cells (60). For instance, in an epidermal growth factor receptor (HER)2positive breast tumor model, IFN- $\gamma \mathrm{R} 1^{\text {low }}$ expressing tumor cells successfully escaped from immune surveillance and stayed dormant from tumor elimination (61).

IFN-based therapy has shown promising outcomes in multiple murine breast cancer models (4T1 and 66cl4), specifically by regulating the metastatic spread of tumor cells to the bone (62, 63). The administration of type I IFN via intravenous injection could reduce tumor burden, stimulate NK cells and effector $\mathrm{CD}^{+} \mathrm{T}$ cells while dampening the immunosuppressive MDSCs in the blood and bone marrow. Notably, these results could limit tumor outgrowth in remote site and eventually increase the metastasisfree survival rate. Clinical trials using IFNs in the solid tumor showed some efficacies. However, the induced moderate-to-severe toxicity issues could not be neglected $(64,65)$.

\subsection{Vaccine Adjuvants}

Adjuvants are derived from DAMPs and/or PAMPs to improve the potency of breast cancer vaccines and treatment by inducing robust innate immune responses. They can stimulate innate immune cells, such as DCs, by binding to the expressed PRRs, including toll-like receptors, C-type lectin receptors, and retinoic acid-inducible gene I-like receptors, nucleotide-binding oligomerization domain-like receptors, or cytosolic STINGdependent DNA sensors (66). Recently, tremendous progress has been made in targeting PRRs and STING pathways for breast cancer treatment (67-71).

\subsubsection{Toll-Like Receptors (TLRs)}

PAMPs or DMAPs recognition by TLRs activates an inflammatory response that promotes the elimination of cancer cells in the host (72). There is evidence that TLR signaling can abrogate immunosuppression by reducing myeloid-derived suppressor cells (MDSCs) while upregulating stimulatory molecules, including CD40, CD80, CD86, and pro-inflammatory cytokines production. These signals can further stimulate a more potent nonspecific innate immunity and bridge the adaptive immune responses against breast cancer (73-75).

Among all these TLR-agonists, poly (I: C) was reported to effectively modulate MDSCs activity in a mice model of breast cancer (76). Poly (I: C) directly bond to TLR3 expressed on the surface of MDSCs, therefore, caused the reduction of circulating and infiltrating MDSCs in breast tumors. In addition, TLR7/8 agonist R484 is another successful adjuvant in breast cancer. The use of R484 alone has been demonstrated to retard tumor growth (68). After repeated intraperitoneal injection of R484, the vasculature density of breast tumors was reduced, and tumor cell apoptosis was induced significantly.

Recently, Zheng et al. reported utilizing a vaccine-based nanosystem as an innate immune stimulator for treating breast tumors (77). They confirmed the importance of TLR7 in APC activation, and the nano-sized innate immune stimulator activated the endosomal TLR7 signaling to promote antigen cross-presentation. Furthermore, it can be potentially used as cancer vaccine adjuvants or immunotherapeutic agents to improve immune checkpoint blockade (ICB) immunotherapy.

\subsubsection{RIG-I-Like Receptors (RLRs)}

RLRs family includes RIG-I and melanoma differentiationassociated gene 5 (MDA5), both of which are cytoplasmic RNA sensors (78). The RNA recognition of RLRs can effectively inhibit breast cancer growth by inducing apoptosis in the IFN-independent manner (79). For example, RIG-I activation mimics viral infection in various cancer types, including breast cancer. The activated RIG-I signaling is associated with NK cell attack, phagocytosis of apoptotic tumor cells, and other immunogenic forms of tumor inhibition $(80,81)$.

More recently, Domankevich et al. applied an intra-tumoral cytoplasmatic delivery agent to directly activate RLR while bypassing endosomal recognition via TLRs (82). They showed the reduced 4T1 triple-negative breast tumors, and the metastasis development was retarded after re-challenge. Another similar study was conducted to deliver poly (I: C) to the cytoplasm in an MDA5-dependent manner while bypassing the TLR3-mediated signaling pathway (69). Furthermore, three human breast cancer cell lines, including MCF-7, MDA-MB-231, and BT-549, were tested to transfect poly(I: C). The transfected cells showed less tumorigenicity when implanting for breast tumor growth. Together, these results suggested that innate adjuvant receptors are emerging targets for antitumor drug therapies.

\subsubsection{NOD-Like Receptors (NLRs)}

NLRs are cytosolic receptors that detect intracellular pathogens and endogenous byproducts from tissue injury. In recent years, targeting innate immune NLR pathways for cancer immunotherapy, including breast cancer, has attracted increasing attention, due to their multiple 
functions in intracellular pathogens detection, initiation of inflammation, and the regulation of tissue repair (83). One such example is that NOD1 has been investigated in breast tumor models and showed protective function in breast tumorigenesis (84). Mice inoculated with NOD1-deficient MCF-7 breast cancer cells exhibited rapid growth and continuous malignancy. Another aggressive Hs578T triple-negative breast cancer cell line was also designated to study the impact of NOD1 and NOD2 receptors (70). In this model, NOD1 overexpression reduced estrogen-induced tumor proliferation, while NOD2 activation led to a remarkable suppression of tumor growth. Numerous findings suggested that NLRs and their downstream signaling factors switch roles during different stages of cancer development, including initiation, elimination, and maintenance (83). Thus, it is necessary to elucidate the immune-stimulatory properties of NLRs in breast cancer and potentially modulate treatment outcomes.

\subsubsection{C-Type Lectins Receptors (CLRs)}

CLRs play a crucial role in facilitating antigen uptake and presentation by MHC molecules (71). Dectin-1 is one typical CLR that can be activated by beta-glucan to regulate the antitumor immune responses. The dectin-1 receptors were expressed mainly on macrophages, neutrophils, dendritic cells, and a subpopulation of T-lymphocytes. Beta-glucan binding to the lectin site of neutrophils or NK cells generated a primed state of the receptor, capable of recruiting tumoricidal granulocytes for cytotoxic killing $(71,85)$. Oral administration of beta-glucan has been shown to stimulate peripheral blood monocytes expansion and activation in patients with metastatic breast cancer (86), similarly, another clinical trial suggested $\beta$-glucans as useful adjuvants in improving life quality for breast carcinoma patients during chemotherapy (87). Lectin-like oxidized-lowdensity lipoprotein (oxLDL) receptor-1 (LOX-1) was reported to induce TNF- $\alpha$ expression, cellular adhesion and transendothelial migration of MDA-MB-231 breast cancer cells (88). Besides, LOX-1 expression on DCs was associated with cross-presentation and activation of cytotoxic CD8+ T cells (89, 90 ), and meanwhile mediated B cell differentiation and migration (91). Moreover, high levels of LOX-1 expression was found on MDSCs from peripheral blood and tumor of cancer patients but not on MDSCs from healthy donors (92). Therefore, future studies remain to be performed to apply these potential CLRs as anti-breast cancer vaccine adjuvants.

\subsubsection{Cytosolic Stimulator of Interferon Genes (STING)-Dependent DNA Sensor}

STING is recently discovered as an intracellular DNA recognition receptor that can induce type I interferon production and host innate immune activation. Synthetic STING agonists have been found to regulate tumorigenesis and potently induce antitumor immunity in metastatic breast cancer (93). In addition to its direct inhibitory effect in tumor cells, emerging evidence suggested that STING agonists function as vaccine adjuvants to promote therapeutic response.
Among the STING agonists, 5,6-Dimethylxanthenone-4acetic Acid (DMXAA) was shown to mediate robust antitumor innate immune responses in MMTV-PyMT tumor bearing mice by vessel destruction and amplified immune cell infiltration (94). However, DMXAA was a murine STING restricted agonist and failed in targeting human breast cancer in phase III clinical trials. Based on these findings, several STING agonists have been generated to target human species while preserving the ability to induce strong type I IFN. Cyclic dinucleotides, such as cyclic diguanylate monophosphate (c-di-GMP), cyclic deadenylate (c-di-AMP), and cyclic guanosine monophosphateadenosine monophosphate (cGAMP), have been shown to improve vaccination in multiple cancer types, including breast tumor (95-97). Similarly, c-di-GMP could inhibit the spread of metastasis and tumor size in 4T1 metastatic breast tumors. In situ delivery of a STING-activating cyclic dinucleotide, ADU-S100/ MIW815, against established HER2 ${ }^{+}$breast tumors overcame immune tolerance and further induced tumor regression (98). Moreover, nanoparticle delivery of STING-activating cGAMP was recently demonstrated to inhibit tumors in a genetically engineered mouse model of basal-like triple-negative breast cancer C3 (1)Tag, which was insensitive to checkpoint blockade therapy (67). To further explore the function of STING targeted therapy, increasing preclinical experiments and clinical trials are undergoing investigation in breast cancer and other cancer types $(99,100)$.

\subsection{Targeting Innate Immunity in Combination With Other Breast Cancer Therapies}

The antitumor response induced by one singular innate immune reagent can be limited, hindering potential therapeutic application. Synergistic activation of innate and efferent arms represents the future therapeutic modality owing to the high potency and specificity for translational medicine. Various approaches have been explored to reduce toxicity and facilitate both innate and adaptive antitumor immune responses. STINGdeficient mice showed impaired $\mathrm{CD}^{+} \mathrm{T}$ cells, and these mice were more vulnerable to tumor progression and resistance to immunotherapy. Thus, STING targeting therapy had a pivotal function in enhancing immune checkpoint blockade response (ICB) (101). Remarkably, in the ICB-resistant breast cancer model, combination treatment of IFN inhibitors and ICB led to complete tumor eradication and survival (102). This study demonstrated that inhibition of the IFN signaling pathway could restore the immune responses to ICB, which largely expands the use of immunotherapies for highly extensive ICB-combinationtherapy-resistant tumors.

Moreover, when combined with ionizing radiation, nanovaccines delivery of STING activator also reversed the immunosuppressive tumor microenvironment, and this combined approach has been proved as safe and effective radioimmunotherapy for primary and metastatic tumors (103). Interestingly, plasmacytoid dendritic cells ( $\mathrm{pDC}$ ) promote immunosuppression within the tumor microenvironment. 
TABLE 1 | Factors and mechanisms related to anticancer innate immunity and summary of agents in the use of breast cancer immunotherapy.

\begin{tabular}{|c|c|c|c|c|c|}
\hline $\begin{array}{l}\text { Innate immune } \\
\text { pathway/ } \\
\text { receptor }\end{array}$ & Classification & Role in cancer immunity & Innate cells & Agent & Ref \\
\hline $\begin{array}{l}\text { Colony- } \\
\text { stimulating } \\
\text { factor }\end{array}$ & $\begin{array}{l}\text { M-CSF, G-CSF, GM-CSF, } \\
\| \mathrm{L}-3\end{array}$ & $\begin{array}{l}\text { regulate the proliferation, maturation, and apoptosis } \\
\text { of myeloid cell }\end{array}$ & $\begin{array}{l}\text { DC, TAM, MDSC, } \\
\text { neutrophils, NK cell }\end{array}$ & $\begin{array}{l}\text { the anti-CSF1R antibody, } \\
\text { CSF1R inhibitor }\end{array}$ & (53) \\
\hline Interferon & $\begin{array}{l}\text { Type I IFN (IFN- } \alpha \text { and } \\
\text { IFN- } \beta \text {, etc.) } \\
\text { Type II IFN (IFN- } \gamma \text { R1 and } \\
\text { IFN- } \gamma \text { R2) }\end{array}$ & $\begin{array}{l}\text { maturation of dendritic cells; recruit NK cell and T } \\
\text { helper cells; polarize macrophage phenotypes; }\end{array}$ & $\begin{array}{l}\text { Drug: FLAC with GM- } \\
\text { CSF }\end{array}$ & IFN- $\alpha 2 a$, IFN- $\alpha 2 b$ & $(41,105)$ \\
\hline $\begin{array}{l}\text { TLRs/Toll-like } \\
\text { receptors }\end{array}$ & $\begin{array}{l}\text { Cell surface TLRs (TLR1, } \\
\text { TLR2, TLR4, TLR5, TLR6, } \\
\text { and TLR10) } \\
\text { Intracellular TLRs (TLR3, } \\
\text { TLR7, TLR8, TLR9, } \\
\text { TLR11, TLR12, and } \\
\text { TLR13) }\end{array}$ & $\begin{array}{l}\text { mediate both immune surveillance and immune } \\
\text { tolerance; activates inflammatory response; cancer } \\
\text { vaccine adjuvants or immunotherapeutic agent }\end{array}$ & $\begin{array}{l}\text { DC, TAM, MDSC, } \\
\text { neutrophils, NK cell, } \\
\text { basophils, eosinophils, } \\
\text { mast cell }\end{array}$ & $\begin{array}{l}\text { TLR3 agonist Polyl:C, } \\
\text { TLR4 agonist LPS, TLR7/8 } \\
\text { imiquimod, TLR9 agonist } \\
\text { CpG ODNs }\end{array}$ & $\begin{array}{l}(69) \\
(68)\end{array}$ \\
\hline $\begin{array}{l}\text { RLRs/RIG-I-like } \\
\text { receptors }\end{array}$ & RIG-I and MDA5 & $\begin{array}{l}\text { promote transcription factor IRF3 and NF- } \mathrm{kB} \text {; affect } \\
\text { the secretion of inflammatory cytokines; promote } \\
\text { phagocytosis of apoptotic tumor cells }\end{array}$ & $\begin{array}{l}\text { DC, TAM, MDSC, } \\
\text { neutrophils, NK cell, } \\
\text { basophils, eosinophils, } \\
\text { mast cell }\end{array}$ & $\begin{array}{l}\text { RIG-I activator MK- } 4621 \\
\text { Bo-112 }\end{array}$ & $\begin{array}{c}(78) \\
(80,81) \\
(79)\end{array}$ \\
\hline $\begin{array}{l}\text { NLRs/NOD-like } \\
\text { receptors }\end{array}$ & $\begin{array}{l}\text { NLRA, NLRB, NLRC, } \\
\text { NLRP, NLRX }\end{array}$ & $\begin{array}{l}\text { intracellular pathogens detection; initiation of } \\
\text { inflammation; regulation of tissue repair; induce type } \\
\text { I IFN secretion }\end{array}$ & $\begin{array}{l}\text { DC, TAM, MDSC, } \\
\text { neutrophils, NK cell, mast } \\
\text { cell }\end{array}$ & $\begin{array}{l}\text { NOD-2 agonist } \\
\text { mifamurtide }\end{array}$ & (83). \\
\hline $\begin{array}{l}\text { CLRs, C-type } \\
\text { lectin receptors }\end{array}$ & Dectin-1 & $\begin{array}{l}\text { facilitate antigen uptake and presentation by } \mathrm{MHC} \\
\text { molecules; recruiting tumoricidal granulocytes }\end{array}$ & DC, TAM, neutrophils & CMB305, imprime PGG. & $(71,85)$ \\
\hline CDS, Cytosolic & STING-dependent & promote AIM2 inflammasome activation; induce the & DC, TAM, MDSC, mast & STING agonists MK-1454, & $(94)$ \\
\hline
\end{tabular}

However, they are the major type I IFN producers in response to TLR7 and TLR9 activation. Inspired by these features, $\mathrm{Wu}$ et al. introduced TLR7 ligand imiquimod (IMQ) and the TLR9 ligand $\mathrm{CpG}$ to target $\mathrm{pDC}$, and the combined treatment induced a more potent effect compared to the single-agent (104). Collectively, these emerging strategies (Table 1) suggested that rationally designed innate immunostimulatory adjuvants can be potentially efficient and versatile for developing combination immunotherapy for breast cancer.

\section{CLINICAL APPLICATIONS AND CURRENT TRIALS OF INNATE IMMUNITY- BASED BREAST CANCER THERAPY}

So far, several breast cancer immunotherapies have broken immune tolerance in clinical applications, giving novel promises for cancer therapy. We expansively summarized the clinical studies targeting innate immunity for breast cancer therapy (Table 2). Several clinical applications targeting innate immunity, using colony-stimulating factors, stimulator of interferon genes along with their agonistic ligands for toll-like receptors, showed these clinical treatments not merely regard as vaccine adjuvants but as well as antitumor agents. Moreover, combination therapies have revealed superior efficacy, may offer a new promise for the development of immune therapy. Herein, we focus on completed or ongoing clinical trials of innate immunity-based breast cancer therapy. Currently there are 16 clinical trials from phase 1 to 4 using colony-stimulating factors (CSF) together with chemotherapy or radiotherapy for breast cancer treatment. CSF was mainly used for enhance the efficacy of chemotherapeutic drugs such as paclitaxel, ciprofloxacin and reduced the neutropenia caused by those drugs. The safety of CSF or PEGylated CSF has been verified in human being. The clinical trials of interferons and toll-like receptors are mainly at stage 1 or 2 to study the safety and optimize the tolerated doses. There is also one stage 1 trial using cytosolic STING-dependent drug to determine the side effects and safety.

\section{CONCLUSION AND FUTURE DIRECTIONS}

The innate immunity exerts essential roles in shaping breast cancer development and altering tumor microenvironment through the recruitment of circulating innate immune cells and trigger the activation of adaptive immune cells, or through the functional skewing of residential immune cells by the secreted cytokines, growth factors and PRRs-mediated interaction. To understand the breast tumor microenvironment, preclinical studies have been shown that innate immune cells and the secreted cytokines have multifaceted roles that either promote or suppress breast tumor during disease progression or therapeutic responses. For instance, when upon interaction with tumor antigen via TLR or STING that primarily expressed on DCs and macrophages, these stimulated 
TABLE 2 | Clinical applications and current trials of innate immunity-based breast cancer therapy.

\begin{tabular}{|c|c|c|c|c|c|}
\hline Target & Phase & $\begin{array}{l}\text { Clinical } \\
\text { status }\end{array}$ & Summary & Interventions & $\begin{array}{l}\text { Clinical trial } \\
\text { identifiers }\end{array}$ \\
\hline $\begin{array}{l}\text { Colony- } \\
\text { stimulating } \\
\text { factors }\end{array}$ & 1 & $\begin{array}{l}\text { Active, not } \\
\text { recruiting }\end{array}$ & $\begin{array}{l}\text { Patients' tumor cells were used to formulate a vaccine to } \\
\text { stimulate their immunity by secreting granulocyte-macrophage } \\
\text { colony-stimulating factor (GM-CSF). }\end{array}$ & $\begin{array}{l}\text { Biological: Autologous, Lethally Irradiated Breast } \\
\text { Cancer Cells }\end{array}$ & СТ00317603 \\
\hline $\begin{array}{l}\text { Colony- } \\
\text { stimulating } \\
\text { factors }\end{array}$ & 2 & Completed & $\begin{array}{l}\text { GM-CSF was used to improve chemotherapy-induced toxicity } \\
\text { in metastatic/locally advanced breast cancer. }\end{array}$ & Drug: FLAC with GM-CSF & NCT00001239 \\
\hline $\begin{array}{l}\text { Colony- } \\
\text { stimulating } \\
\text { factors }\end{array}$ & 3 & Completed & $\begin{array}{l}\text { FLAC chemotherapy and GM-CSF or PIXY321 for patients } \\
\text { with locally advanced breast cancer. }\end{array}$ & Drug: FLAC chemotherapy with GM-CSF & NCT00001338 \\
\hline $\begin{array}{l}\text { Colony- } \\
\text { stimulating } \\
\text { factors }\end{array}$ & 1 & Completed & $\begin{array}{l}\text { Treatment of IL-3 alone or in combination with GM-CSF after } \\
\text { FLAC chemotherapy was conducted to study the maximal } \\
\text { dose of IL- } 3 \text { in patients with metastatic breast cancer. }\end{array}$ & Drug: IL-3 & NCT00001269 \\
\hline $\begin{array}{l}\text { Colony- } \\
\text { stimulating } \\
\text { factors }\end{array}$ & 1 & Completed & $\begin{array}{l}\text { Treatment of paclitaxel (weekly) combined with radiotherapy } \\
\text { (biweekly) was performed to study toxicity and response rate. }\end{array}$ & $\begin{array}{l}\text { Drug: Paclitaxel, Vinorelbine, Filgrastim } \\
\text { Radiation: Radiation }\end{array}$ & NCT00724386 \\
\hline $\begin{array}{l}\text { Colony- } \\
\text { stimulating } \\
\text { factors }\end{array}$ & 3 & Completed & $\begin{array}{l}\text { The biosafety and efficacy of injecting GSF fusion protein and } \\
\text { recombinant human serum albumin were studied for } \\
\text { preventing chemotherapy-induced neutropenia. }\end{array}$ & Drug: rHSA-GCSF and G-CSF & NCT03251768 \\
\hline $\begin{array}{l}\text { Colony- } \\
\text { stimulating } \\
\text { factors }\end{array}$ & 4 & Completed & $\begin{array}{l}\text { Treatment of prophylaxis combined with either ciprofloxacin or } \\
\text { G-CSF was conducted to diminish chemotherapy-induced } \\
\text { febrile neutropenia. }\end{array}$ & $\begin{array}{l}\text { Drug: Ciprofloxacin } \\
\text { Drug: Neupogen }\end{array}$ & NCT02816112 \\
\hline $\begin{array}{l}\text { Colony- } \\
\text { stimulating } \\
\text { factors }\end{array}$ & 4 & $\begin{array}{l}\text { Not yet } \\
\text { recruiting }\end{array}$ & $\begin{array}{l}\text { Post chemotherapy, patients received a second injection of } \\
\text { PEG-rhG-CSF to prevent bone marrow suppression and/or } \\
\text { febrile neutropenia in breast cancer. }\end{array}$ & Drug: PEG-rhG-CSF & NCT04477616 \\
\hline $\begin{array}{l}\text { Colony- } \\
\text { stimulating } \\
\text { factors }\end{array}$ & 1 & Completed & $\begin{array}{l}\text { Treatment of different doses of rHSA/GCSF to study the } \\
\text { safety and tolerance in breast cancer patients. }\end{array}$ & Drug: rHSA/GCSF & NCT03246009 \\
\hline $\begin{array}{l}\text { Colony- } \\
\text { stimulating } \\
\text { factors }\end{array}$ & 4 & $\begin{array}{l}\text { Not yet } \\
\text { recruiting }\end{array}$ & $\begin{array}{l}\text { Treatment of PEG-rhG-CSF as the primary prevention of } \\
\text { neutropenia to study the clinical efficacy, tolerance, and safety } \\
\text { in early breast cancer patients. }\end{array}$ & Drug: PEG-rhG-CSF & NCT04009941 \\
\hline $\begin{array}{l}\text { Colony- } \\
\text { stimulating } \\
\text { factors }\end{array}$ & 2 & Completed & $\begin{array}{l}\text { To study tumor response rate and survival rate in patients } \\
\text { after GM-CSF treatment. }\end{array}$ & $\begin{array}{l}\text { Drug: Herceptin } \\
\text { Drug: GM-CSF }\end{array}$ & NCT00429104 \\
\hline $\begin{array}{l}\text { Colony- } \\
\text { stimulating } \\
\text { factors }\end{array}$ & 2 & Completed & $\begin{array}{l}\text { To determine the dose and safety of combined rintatolimod } \\
\text { and GM-CSF treatment. }\end{array}$ & $\begin{array}{l}\text { Biological: HER-2/neu peptide vaccine } \\
\text { Biological: sargramostim, Rintatolimod }\end{array}$ & NCT01355393 \\
\hline $\begin{array}{l}\text { Colony- } \\
\text { stimulating } \\
\text { factors }\end{array}$ & 1 & Completed & $\begin{array}{l}\text { To determine the dose and safety of co-treatment of vaccine, } \\
\text { Montanide ISA-51 and sargramostim for stage IV breast } \\
\text { cancer patients. }\end{array}$ & $\begin{array}{l}\text { Biological: incomplete Freund's adjuvant, } \\
\text { Sargramostim } \\
\text { Biological: telomerase: } 540-548 \text { peptide vaccine }\end{array}$ & NCT00079157 \\
\hline $\begin{array}{l}\text { Colony- } \\
\text { stimulating } \\
\text { factors }\end{array}$ & 3 & Completed & $\begin{array}{l}\text { To study the side effect and efficacy of administering } \\
\text { NeuVax }{ }^{\text {TM }} \text { with sargramostim (GM-CSF). }\end{array}$ & $\begin{array}{l}\text { Biological: NeuVax }{ }^{\mathrm{TM}} \text { vaccine, Leukine }{ }^{\circledR} \\
\text { (sargramostim, GM-CSF) }\end{array}$ & NCT01479244 \\
\hline $\begin{array}{l}\text { Colony- } \\
\text { stimulating } \\
\text { factors }\end{array}$ & 2 & Completed & $\begin{array}{l}\text { To determine the efficacy of vaccine and sargramostim (GM- } \\
\text { CSF) in post-surgical female patients diagnosed as stage II/III } \\
\text { breast cancer with metastasis to the lymph nodes. }\end{array}$ & $\begin{array}{l}\text { Biological: recombinant fowlpox-CEA(6D)/TRICOM } \\
\text { vaccine, recombinant vaccinia-CEA(6D)-TRICOM } \\
\text { vaccine, Sargramostim } \\
\text { Drug: cyclophosphamide, Doxorubicin } \\
\text { hydrochloride, Paclitaxel } \\
\text { Radiation: radiation therapy }\end{array}$ & NCT00052351 \\
\hline $\begin{array}{l}\text { Colony- } \\
\text { stimulating } \\
\text { factors }\end{array}$ & 2 & Completed & $\begin{array}{l}\text { To compare the efficacy of the GP2 peptide vaccine and GM- } \\
\text { CSF in breast cancer patients. }\end{array}$ & $\begin{array}{l}\text { Biological: GP2 peptide + GM-CSF vaccine, GM- } \\
\text { CSF (sargramostim), AE37 + GM-CSF vaccine, }\end{array}$ & NCT00524277 \\
\hline Interferons & 2 & Terminated & $\begin{array}{l}\text { To determine the combined efficacy of capecitabine and } \\
\text { interferon alfa-2a in breast cancer patients with recurrent or } \\
\text { progressive brain metastases. }\end{array}$ & $\begin{array}{l}\text { PEG-interferon alfa-2a } \\
\text { Drug: Capecitabine }\end{array}$ & NCT00227656 \\
\hline Interferons & 2 & Recruiting & $\begin{array}{l}\text { To optimize the dose and safety of delivering interferon- } \\
\text { gamma and paclitaxel/trastuzumab/pertuzumab in HER2 } \\
\text { positive breast cancer patients. }\end{array}$ & $\begin{array}{l}\text { Biological: Interferon-gamma } \\
\text { Drug: Paclitaxel, Trastuzumab, Pertuzumab }\end{array}$ & NCT03112590 \\
\hline Interferons & 1 & Recruiting & $\begin{array}{l}\text { To explore the safe dose range of IFN- } \alpha-2 a \text { and the human } \\
\text { tolerance index. }\end{array}$ & Drug: IFN- $\alpha-2 a$ & NCT04522557 \\
\hline Interferons & 2 & Completed & $\begin{array}{l}\text { To determine the efficacy of combining cyclophosphamide } \\
\text { and tumor cell vaccine in cancer participants at high risk of } \\
\text { recurrence. }\end{array}$ & $\begin{array}{l}\text { Biological: allogeneic tumor cell vaccine, autologous } \\
\text { tumor cell vaccine, recombinant interferon alfa, } \\
\text { recombinant interferon-gamma, sargramostim }\end{array}$ & NCT00002475 \\
\hline
\end{tabular}


TABLE 2 | Continued

\begin{tabular}{|c|c|c|c|c|c|}
\hline Target & Phase & $\begin{array}{l}\text { Clinical } \\
\text { status }\end{array}$ & Summary & Interventions & $\begin{array}{l}\text { Clinical trial } \\
\text { identifiers }\end{array}$ \\
\hline Interferons & 1 & Completed & $\begin{array}{l}\text { To determine the safety and optimal dose of treating } \\
\text { interferon alfa in participants with stage IV solid tumors (breast } \\
\text { cancer), lymphoma, or myeloma. }\end{array}$ & $\begin{array}{l}\text { Drug: cyclophosphamide } \\
\text { Biological: recombinant interferon alpha-1b } \\
\text { Drug: IFN }\end{array}$ & NCT00276536 \\
\hline $\begin{array}{l}\text { Toll-like } \\
\text { receptors }\end{array}$ & 2 & Completed & $\begin{array}{l}\text { To study the optimal dose and efficacy of Imiquimod together } \\
\text { with cyclophosphamide and radiotherapy in participants with } \\
\text { breast cancer and skin metastases. }\end{array}$ & $\begin{array}{l}\text { Radiation: Radiation } \\
\text { Drug: Imiquimod } \\
\text { Drug: Cyclophosphamide }\end{array}$ & NCT01421017 \\
\hline $\begin{array}{l}\text { Toll-like } \\
\text { receptors }\end{array}$ & 1 & Terminated & $\begin{array}{l}\text { To study the dose range of cyclophosphamide, pegfilgrastim, } \\
\text { and TLR8 agonist VTX-2337 (CyNeuMoto). }\end{array}$ & $\begin{array}{l}\text { Drug: Cyclophosphamide } \\
\text { Biological: Pegfilgrastim, TLR8 Agonist VTX-2337 }\end{array}$ & NCT02650635 \\
\hline $\begin{array}{l}\text { Toll-like } \\
\text { receptors }\end{array}$ & 2 & Completed & $\begin{array}{l}\text { To study the side effect and efficacy of Imiquimod in patients } \\
\text { with breast cancer and metastases to skin or chest wall } \\
\text { recurrences. }\end{array}$ & Drug: Imiquimod & NCT00899574 \\
\hline $\begin{array}{l}\text { Toll-like } \\
\text { receptors }\end{array}$ & 2 & Completed & $\begin{array}{l}\text { To determine the safe dose of Imiquimod together with } \\
\text { Abraxane. }\end{array}$ & Drug: Imiquimod, Abraxane & NCT00821964 \\
\hline $\begin{array}{l}\text { Toll-like } \\
\text { receptors }\end{array}$ & 2 & Completed & $\begin{array}{l}\text { To study the efficacy of } 852 \mathrm{~A} \text { in metastatic breast cancer } \\
\text { patients. }\end{array}$ & Drug: $852 \mathrm{~A}$ & NCT00319748 \\
\hline $\begin{array}{l}\text { Toll-like } \\
\text { receptors }\end{array}$ & 1 & Terminated & $\begin{array}{l}\text { To study the immunogenicity of administering a TLR3 vaccine } \\
\text { together with poly-ICLC in patients with stage I.B. to IIIA } \\
\text { breast cancer. }\end{array}$ & $\begin{array}{l}\text { Biological: poly-ICLC } \\
\text { Biological: Peptides from Her-2/neu, CEA, \& CTA, } \\
\text { Peptide-te }\end{array}$ & NCT01532960 \\
\hline $\begin{array}{l}\text { Cytosolic } \\
\text { STING- } \\
\text { dependent }\end{array}$ & 1 & Recruiting & $\begin{array}{l}\text { To determine the side effect and efficacy of E7766 by } \\
\text { intratumorally administrated in patients with advanced solid } \\
\text { tumors or lymphomas. }\end{array}$ & Drug: E7766 & NCT04144140 \\
\hline
\end{tabular}

innate immune cells undergo maturation or repolarization (e.g. immature DCs differentiate into mature DCs; pro-tumoral TAMs repolarize towards anti-tumoral M1 macrophages). They secrete IL-12 and type I IFNs that can prime and activate tumor specific $\mathrm{CD}^{+} \mathrm{T}$ cells for cytotoxic killing against breast tumor cells. The secreted IL-12 and type I IFNs also can activate NK cells for lysing tumor cells. Meanwhile, breast tumor cells synthesize and secret TGF $\beta$ that directly or indirectly target various immune cells, which altogether mediate the immune escape for invasion and metastasis (46). This also leads to another opportunity of developing routine immunoprofiling analysis of breast tumors and patients, which should be matched to effective strategy during treatment planning and prognosis. Therefore, understanding the interaction among innate immune cells with breast tumor microenvironment can aid to select therapeutic strategy for achieving successful outcomes based on the personalized immunoprofiling information.

Although $\mathrm{T}$ cell-based immunotherapies have achieved breakthrough outcomes in many cancer types, including some breast cancers, patients with poor infiltrating lymphocytes had limited or no response. To tackle the difficult-to-treat breast cancers or enhance the antitumor responsiveness of immunotherapy, numerous preclinical studies and early clinical trials have been conducted to activate innate immune cell populations or sensing pathways alone or in combination with adaptive immune therapies. One clinical study NCT02981303 is conducted on metastatic triple negative breast cancer (TNBC) patients to test the combination of Dectin Receptor agonist Imprime PGG and the immune checkpoint blocker pembrolizumab. They showed robust infiltration of activated myeloid cells and TILs associated with promising synergistic anti-tumor effects. Another ongoing phase I trial NCT03841110 is conducted to evaluate the combined effect of adoptive transferred NK cells (iPSC-derived) and anti-PD-1 antibodies (nivolumab or pembrolizumab). Although the trial NCT03172936 was recently terminated, their preliminary results suggest that STING agonist ADU-S100 in combination with the PD-1 blocker spartalizumab was well tolerated and mediated some clinical activity in patients with PD-1-naïve TNBC $(99,106)$. Therefore, increasing progress is being made to manage patient safety and determining nontoxic doses of single-agent or combination drugs that exhibit effective antitumor responses. Current data encourages a continued exploration of these strategies for translational application.

\section{DATA AVAILABILITY STATEMENT}

The original contributions presented in the study are included in the article/supplementary material. Further inquiries can be directed to the corresponding authors.

\section{AUTHOR CONTRIBUTIONS}

NC designed this study. YY, CX, FC, and QL wrote the manuscript. NC revised the manuscript. All authors contributed to the article and approved the submitted version.

\section{FUNDING}

The authors' work is supported by a grant from the United States National Cancer Institute/National Institute of Health (NCI/ NIH K00 CA223019 to NC). 


\section{REFERENCES}

1. Siegel RL, Miller KD, Jemal A. Cancer Statistics, 2020. CA Cancer J Clin (2020) 70(1):7-30. doi: 10.3322/caac.21590

2. Cancer Genome Atlas, N. Comprehensive Molecular Portraits of Human Breast Tumours. Nature (2012) 490(7418):61-70. doi: 10.1038/nature11412

3. Polyak K. Heterogeneity in Breast Cancer. J Clin Invest (2011) 121 (10):3786-8. doi: 10.1172/JCI60534

4. Polyak K. Breast Cancer: Origins and Evolution. J Clin Invest (2007) 117 (11):3155-63. doi: 10.1172/JCI33295

5. Lim B, Woodward WA, Wang X, Reuben JM, Ueno NT. Inflammatory Breast Cancer Biology: The Tumour Microenvironment is Key. Nat Rev Cancer (2018) 18(8):485-99. doi: 10.1038/s41568-018-0010-y

6. Grivennikov SI, Greten FR, Karin M. Immunity, Inflammation, and Cancer. Cell (2010) 140(6):883-99. doi: 10.1016/j.cell.2010.01.025

7. Todoric J, Antonucci L, Karin M. Targeting Inflammation in Cancer Prevention and Therapy. Cancer Prev Res (Phila) (2016) 9(12):895-905. doi: 10.1158/1940-6207.CAPR-16-0209

8. Comen EA, Bowman RL, Kleppe M. Underlying Causes and Therapeutic Targeting of the Inflammatory Tumor Microenvironment. Front Cell Dev Biol (2018) 6:56. doi: 10.3389/fcell.2018.00056

9. Segovia-Mendoza M, Morales-Montor J. Immune Tumor Microenvironment in Breast Cancer and the Participation of Estrogen and Its Receptors in Cancer Physiopathology. Front Immunol (2019) 10:348. doi: 10.3389/fimmu.2019.00348

10. Binnewies M, Roberts EW, Kersten K, Chan V, Fearon DF, Merad M, et al. Understanding the Tumor Immune Microenvironment (TIME) for Effective Therapy. Nat Med (2018) 24(5):541-50. doi: 10.1038/s41591-018-0014-x

11. Allinen M, Beroukhim R, Cai L, Brennan C, Lahti-Domenici J, Huang H, et al. Molecular Characterization of the Tumor Microenvironment in Breast Cancer. Cancer Cell (2004) 6(1):17-32. doi: 10.1016/j.ccr.2004.06.010

12. Gatti-Mays ME, Balko JM, Gameiro SR, Bear HD, Prabhakaran S, Fukui J, et al. If We Build it They Will Come: Targeting the Immune Response to Breast Cancer. NPJ Breast Cancer (2019) 5(1):37. doi: 10.1038/s41523-019-0133-7

13. Gonzalez H, Hagerling C, Werb Z. Roles of the Immune System in Cancer: From Tumor Initiation to Metastatic Progression. Genes Dev (2018) 32(1920):1267-84. doi: 10.1101/gad.314617.118

14. Ben-Baruch A. Host Microenvironment in Breast Cancer Development: Inflammatory Cells, Cytokines and Chemokines in Breast Cancer Progression: Reciprocal Tumor-Microenvironment Interactions. Breast Cancer Res (2003) 5(1):31-6. doi: 10.1186/bcr554

15. Valeta-Magara A, Gadi A, Volta V, Walters B, Arju R, Giashuddin S, et al. Inflammatory Breast Cancer Promotes Development of M2 TumorAssociated Macrophages and Cancer Mesenchymal Cells Through a Complex Chemokine Network. Cancer Res (2019) 79(13):3360-71. doi: 10.1158/0008-5472.CAN-17-2158

16. Kresovich JK, O’Brien KM, Xu Z, Weinberg CR, Sandler DP, Taylor JA. Prediagnostic Immune Cell Profiles and Breast Cancer. JAMA Netw Open (2020) 3(1):e1919536. doi: 10.1001/jamanetworkopen.2019.19536

17. Vlaicu P, Mertins P, Mayr T, Widschwendter P, Ataseven B, Hogel B, et al. Monocytes/macrophages Support Mammary Tumor Invasivity by CoSecreting Lineage-Specific EGFR Ligands and a STAT3 Activator. BMC Cancer (2013) 13:197. doi: 10.1186/1471-2407-13-197

18. Joyce JA, Pollard JW. Microenvironmental Regulation of Metastasis. Nat Rev Cancer (2009) 9(4):239-52. doi: 10.1038/nrc2618

19. Granot Z, Henke E, Comen EA, King TA, Norton L, Benezra R. Tumor Entrained Neutrophils Inhibit Seeding in the Premetastatic Lung. Cancer Cell (2011) 20(3):300-14. doi: 10.1016/j.ccr.2011.08.012

20. Mahmoud SM, Paish EC, Powe DG, Macmillan RD, Grainge MJ, Lee AH, et al. Tumor-Infiltrating CD8+ Lymphocytes Predict Clinical Outcome in Breast Cancer. J Clin Oncol (2011) 29(15):1949-55. doi: 10.1200/JCO.2010.30.5037

21. Wang M, Zhang C, Song Y, Wang Z, Wang Y, Luo F, et al. Mechanism of Immune Evasion in Breast Cancer. Onco Targets Ther (2017) 10:1561-73. doi: 10.2147/OTT.S126424

22. Bates GJ, Fox SB, Han C, Leek RD, Garcia JF, Harris AL, et al. Quantification of Regulatory T Cells Enables the Identification of High-Risk Breast Cancer Patients and Those at Risk of Late Relapse. J Clin Oncol (2006) 24(34):537380. doi: 10.1200/JCO.2006.05.9584
23. Martin K, Schreiner J, Zippelius A. Modulation of APC Function and AntiTumor Immunity by Anti-Cancer Drugs. Front Immunol (2015) 6:501. doi: 10.3389/fimmu.2015.00501

24. Newton K, Dixit VM. Signaling in Innate Immunity and Inflammation. Cold Spring Harb Perspect Biol (2012) 4(3):a006049. doi: 10.1101/cshperspect.a006049

25. Garg AD, Agostinis P. Cell Death and Immunity in Cancer: From Danger Signals to Mimicry of Pathogen Defense Responses. Immunol Rev (2017) 280 (1):126-48. doi: 10.1111/imr.12574

26. ten Broeke T, Wubbolts R, Stoorvogel W. MHC Class II Antigen Presentation by Dendritic Cells Regulated Through Endosomal Sorting. Cold Spring Harb Perspect Biol (2013) 5(12):a016873. doi: 10.1101/ cshperspect.a016873

27. Sewell AK. Why Must T Cells be Cross-Reactive? Nat Rev Immunol (2012) 12(9):669-77. doi: 10.1038/nri3279

28. Chen L, Flies DB. Molecular Mechanisms of T Cell Co-Stimulation and CoInhibition. Nat Rev Immunol (2013) 13(4):227-42. doi: 10.1038/nri3405

29. Curtsinger JM, Mescher MF. Inflammatory Cytokines as a Third Signal for $T$ Cell Activation. Curr Opin Immunol (2010) 22(3):333-40. doi: 10.1016/ j.coi.2010.02.013

30. Bottcher JP, Bonavita E, Chakravarty P, Blees H, Cabeza-Cabrerizo M, Sammicheli S, et al. NK Cells Stimulate Recruitment of Cdc1 Into the Tumor Microenvironment Promoting Cancer Immune Control. Cell (2018) 1721022-1037(5):e1014. doi: 10.1016/j.cell.2018.01.004

31. Garrido F, Cabrera T, Aptsiauri N. "Hard" and "Soft" Lesions Underlying the HLA Class I Alterations in Cancer Cells: Implications for Immunotherapy. Int J Cancer (2010) 127(2):249-56. doi: 10.1002/ijc.25270

32. Barry KC, Hsu J, Broz ML, Cueto FJ, Binnewies M, Combes AJ, et al. A Natural Killer-Dendritic Cell Axis Defines Checkpoint Therapy-Responsive Tumor Microenvironments. Nat Med (2018) 24(8):1178-91. doi: 10.1038/ s41591-018-0085-8

33. Barry KC, Krummel MF. A Natural Killer-Dendritic Cell Axis Defines Checkpoint Therapy-Responsive Tumor Microenvironments. Cancer Immunol Res (2019) 7(2):1178-91. doi: 10.1158/2326-6074.Cricimteatiaacr18-Pr04

34. Sica A, Larghi P, Mancino A, Rubino L, Porta C, Totaro MG, et al. Macrophage Polarization in Tumour Progression. Semin Cancer Biol (2008) 18(5):349-55. doi: 10.1016/j.semcancer.2008.03.004

35. Hammerl D, Smid M, Timmermans AM, Sleijfer S, Martens JWM, Debets R. Breast Cancer Genomics and Immuno-Oncological Markers to Guide Immune Therapies. Semin Cancer Biol (2018) 52(Pt 2):178-88. doi: 10.1016/j.semcancer.2017.11.003

36. Ali HR, Chlon L, Pharoah PD, Markowetz F, Caldas C. Patterns of Immune Infiltration in Breast Cancer and Their Clinical Implications: A GeneExpression-Based Retrospective Study. PLoS Med (2016) 13(12):e1002194. doi: 10.1371/journal.pmed.1002194

37. Glajcar A, Szpor J, Pacek A, Tyrak KE, Chan F, Streb J, et al. The Relationship Between Breast Cancer Molecular Subtypes and Mast Cell Populations in Tumor Microenvironment. Virchows Arch (2017) 470 (5):505-15. doi: 10.1007/s00428-017-2103-5

38. Medrek C, Ponten F, Jirstrom K, Leandersson K. The Presence of Tumor Associated Macrophages in Tumor Stroma as a Prognostic Marker for Breast Cancer Patients. BMC Cancer (2012) 12:306. doi: 10.1186/14712407-12-306

39. Svensson S, Abrahamsson A, Rodriguez GV, Olsson AK, Jensen L, Cao Y et al. CCL2 and CCL5 Are Novel Therapeutic Targets for EstrogenDependent Breast Cancer. Clin Cancer Res (2015) 21(16):3794-805. doi: 10.1158/1078-0432.CCR-15-0204

40. Dieci MV, Tsvetkova V, Orvieto E, Piacentini F, Ficarra G, Griguolo G, et al. Immune Characterization of Breast Cancer Metastases: Prognostic Implications. Breast Cancer Res (2018) 20(1):62. doi: 10.1186/s13058-0181003-1

41. Mattiuz R, Brousse C, Ambrosini M, Cancel JC, Bessou G, Mussard J, et al. Type 1 Conventional Dendritic Cells and Interferons are Required for Spontaneous CD4(+) and CD8(+) T-Cell Protective Responses to Breast Cancer. Clin Trans Immunol (2021) 10(7):e1305. doi: 10.1002/cti2.1305

42. Hubert M, Couillault C, Manh TPV, Ollion V, Lopez-Mestre H, Rahmouni N, et al. IFN-III is Selectively Produced by Cdc1 and Predicts Good Clinical Outcome in Human Breast Cancer. Cancer Immunol Res (2020) 8(4):70-0. doi: $10.1158 / 2326-6074$ 
43. Hubert M, Gobbini E, Couillault C, Manh TPV, Doffin AC, Berthet J, et al. IFN-III is Selectively Produced by Cdc1 and Predicts Good Clinical Outcome in Breast Cancer. Sci Immunol (2020) 5(46):eaav3942. doi: 10.1126/sciimmunol.aav3942

44. Chrisikos TT, Zhou YF, Li HS, Babcock RL, Wan XX, Patel B, et al. STAT3 Inhibits CD103(+) Cdc1 Vaccine Efficacy in Murine Breast Cancer. Cancers (2020) 12(1):128. doi: 10.3390/cancers12010128

45. Chrisikos TT, Zhou YF, Li HYS, Babcock RL, Wan XX, Patel B, et al. CD103 $+\mathrm{cDC1}$ Vaccine Efficacy in Murine Breast Cancer is Inhibited by STAT3. J Immunol (2020) 204(1):1226.

46. Shihab I, Khalil BA, Elemam NM, Hachim IY, Hachim MY, Hamoudi RA, et al. Understanding the Role of Innate Immune Cells and Identifying Genes in Breast Cancer Microenvironment. Cancers (Basel) (2020) 12(8):2226. doi: $10.3390 /$ cancers 12082226

47. Kees T, Egeblad M. Innate Immune Cells in Breast Cancer-From Villains to Heroes? J Mammary Gland Biol Neoplasia (2011) 16(3):189-203. doi: 10.1007/s10911-011-9224-2

48. Metcalf D. The Granulocyte-Macrophage Colony-Stimulating Factors. Science (1985) 229(4708):16-22. doi: 10.1126/science.2990035

49. Su X, Xu Y, Fox GC, Xiang J, Kwakwa KA, Davis JL, et al. Breast CancerDerived GM-CSF Regulates Arginase 1 in Myeloid Cells to Promote an Immunosuppressive Microenvironment. J Clin Invest (2021) 131(20): e145296. doi: 10.1172/JCI145296

50. Kumar V, Patel S, Tcyganov E, Gabrilovich DI. The Nature of MyeloidDerived Suppressor Cells in the Tumor Microenvironment. Trends Immunol (2016) 37(3):208-20. doi: 10.1016/j.it.2016.01.004

51. Pinedo HM, Buter J, Luykx-de Bakker SA, Pohlmann PR, van Hensbergen Y, Heideman DA, et al. Extended Neoadjuvant Chemotherapy in Locally Advanced Breast Cancer Combined With GM-CSF: Effect on TumourDraining Lymph Node Dendritic Cells. Eur J Cancer (2003) 39(8):1061-7. doi: 10.1016/s0959-8049(03)00131-x

52. Ogawa T, Kusumoto M, Mizumoto K, Sato N, Tanaka M. Adenoviral GMCSF Gene Transduction Into Breast Cancer Cells Induced Long-Lasting Antitumor Immunity in Mice. Breast Cancer (1999) 6(4):301-4. doi: 10.1007/BF02966444

53. Richardsen E, Uglehus RD, Johnsen SH, Busund LT. Macrophage-Colony Stimulating Factor (CSF1) Predicts Breast Cancer Progression and Mortality. Anticancer Res (2015) 35(2):865-74.

54. Gouon-Evans V, Rothenberg ME, Pollard JW. Postnatal Mammary Gland Development Requires Macrophages and Eosinophils. Development (2000) 127(11):2269-82. doi: 10.1242/dev.127.11.2269

55. Hollmen M, Karaman S, Schwager S, Lisibach A, Christiansen AJ, Maksimow M, et al. G-CSF Regulates Macrophage Phenotype and Associates With Poor Overall Survival in Human Triple-Negative Breast Cancer. Oncoimmunology (2016) 5(3):e1115177. doi: 10.1080/2162402X.2015.1115177

56. Broad RV, Jones SJ, Teske MC, Wastall LM, Hanby AM, Thorne JL, et al. Inhibition of Interferon-Signalling Halts Cancer-Associated FibroblastDependent Protection of Breast Cancer Cells From Chemotherapy. $\mathrm{Br} J$ Cancer (2021) 124(6):1110-20. doi: 10.1038/s41416-020-01226-4

57. Provance OK, Lewis-Wambi J. Deciphering the Role of Interferon Alpha Signaling and Microenvironment Crosstalk in Inflammatory Breast Cancer. Breast Cancer Res (2019) 21(1):59. doi: 10.1186/s13058-019-1140-1

58. Smyth MJ, Godfrey DI, Trapani JA. A Fresh Look at Tumor Immunosurveillance and Immunotherapy. Nat Immunol (2001) 2(4):2939. doi: $10.1038 / 86297$

59. Shankaran V, Ikeda H, Bruce AT, White JM, Swanson PE, Old LJ, et al. IFNgamma and Lymphocytes Prevent Primary Tumour Development and Shape Tumour Immunogenicity. Nature (2001) 410(6832):1107-11. doi: $10.1038 / 35074122$

60. Laoui D, Movahedi K, Van Overmeire E, Van den Bossche J, Schouppe E, Mommer C, et al. Tumor-Associated Macrophages in Breast Cancer: Distinct Subsets, Distinct Functions. Int J Dev Biol (2011) 55(7-9):861-7. doi: $10.1387 / \mathrm{ijdb} .113371 \mathrm{dl}$

61. Kmieciak M, Payne KK, Wang XY, Manjili MH. IFN-Gamma Ralpha is a Key Determinant of CD8+ T Cell-Mediated Tumor Elimination or Tumor Escape and Relapse in FVB Mouse. PLoS One (2013) 8(12):e82544. doi: 10.1371/journal.pone.0082544

62. Rautela J, Baschuk N, Slaney CY, Jayatilleke KM, Xiao K, Bidwell BN, et al. Loss of Host Type-I IFN Signaling Accelerates Metastasis and Impairs NK-
Cell Antitumor Function in Multiple Models of Breast Cancer. Cancer Immunol Res (2015) 3(11):1207-17. doi: 10.1158/2326-6066.CIR-15-0065

63. Slaney CY, Moller A, Hertzog PJ, Parker BS. The Role of Type I Interferons in Immunoregulation of Breast Cancer Metastasis to the Bone. Oncoimmunology (2013) 2(1):e22339. doi: 10.4161/onci.22339

64. Ravandi F, Estrov Z, Kurzrock R, Breitmeyer JB, Maschek BJ, Talpaz M. A Phase I Study of Recombinant Interferon-Beta in Patients With Advanced Malignant Disease. Clin Cancer Res (1999) 5(12):3990-8.

65. Castro F, Cardoso AP, Goncalves RM, Serre K, Oliveira MJ. InterferonGamma at the Crossroads of Tumor Immune Surveillance or Evasion. Front Immunol (2018) 9:847. doi: 10.3389/fimmu.2018.00847

66. Kawai T, Akira S. The Role of Pattern-Recognition Receptors in Innate Immunity: Update on Toll-Like Receptors. Nat Immunol (2010) 11(5):37384. doi: $10.1038 /$ ni. 1863

67. Cheng N, Watkins-Schulz R, Junkins RD, David CN, Johnson BM, Montgomery SA, et al. A Nanoparticle-Incorporated STING Activator Enhances Antitumor Immunity in PD-L1-Insensitive Models of TripleNegative Breast Cancer. JCI Insight (2018) 3(22):e120638. doi: 10.1172/ jci.insight.120638

68. Yin T, He S, Wang Y. Toll-Like Receptor 7/8 Agonist, R848, Exhibits Antitumoral Effects in a Breast Cancer Model. Mol Med Rep (2015) 12 (3):3515-20. doi: $10.3892 / \mathrm{mmr} .2015 .3885$

69. Inao $\mathrm{T}$, Harashima $\mathrm{N}$, Monma $\mathrm{H}$, Okano $\mathrm{S}$, Itakura $\mathrm{M}$, Tanaka $\mathrm{T}$, et al. Antitumor Effects of Cytoplasmic Delivery of an Innate Adjuvant Receptor Ligand, Poly(I:C), on Human Breast Cancer. Breast Cancer Res Treat (2012) 134(1):89-100. doi: 10.1007/s10549-011-1930-3

70. Velloso FJ, Sogayar MC, Correa RG. Expression and In Vitro Assessment of Tumorigenicity for NOD1 and NOD2 Receptors in Breast Cancer Cell Lines. BMC Res Notes (2018) 11(1):222. doi: 10.1186/s13104-018-3335-4

71. Temizoz B, Kuroda E, Ishii KJ. Vaccine Adjuvants as Potential Cancer Immunotherapeutics. Int Immunol (2016) 28(7):329-38. doi: 10.1093/ intimm/dxw015

72. Kaczanowska S, Joseph AM, Davila E. TLR Agonists: Our Best Frenemy in Cancer Immunotherapy. J Leukoc Biol (2013) 93(6):847-63. doi: 10.1189/ jlb.1012501

73. Watts C, West MA, Zaru R. TLR Signalling Regulated Antigen Presentation in Dendritic Cells. Curr Opin Immunol (2010) 22(1):124-30. doi: 10.1016/ j.coi.2009.12.005

74. Iwasaki A, Medzhitov R. Control of Adaptive Immunity by the Innate Immune System. Nat Immunol (2015) 16(4):343-53. doi: 10.1038/ni.3123

75. Iwasaki A, Medzhitov R. Regulation of Adaptive Immunity by the Innate Immune System. Science (2010) 327(5963):291-5. doi: 10.1126/science.1183021

76. Forghani P, Waller EK. Poly (I: C) Modulates the Immunosuppressive Activity of Myeloid-Derived Suppressor Cells in a Murine Model of Breast Cancer. Breast Cancer Res Treat (2015) 153(1):21-30. doi: 10.1007/s10549015-3508-y

77. Zheng DW, Gao F, Cheng Q, Bao P, Dong X, Fan JX, et al. A Vaccine-Based Nanosystem for Initiating Innate Immunity and Improving Tumor Immunotherapy. Nat Commun (2020) 11(1):1985. doi: 10.1038/s41467020-15927-0

78. Elion DL, Cook RS. Harnessing RIG-I and Intrinsic Immunity in the Tumor Microenvironment for Therapeutic Cancer Treatment. Oncotarget (2018) 9 (48):29007-17. doi: 10.18632/oncotarget.25626

79. Wu Y, Wu X, Wu L, Wang X, Liu Z. The Anticancer Functions of RIG-I-Like Receptors, RIG-I and MDA5, and Their Applications in Cancer Therapy. Transl Res (2017) 190:51-60. doi: 10.1016/j.trsl.2017.08.004

80. Poeck H, Besch R, Maihoefer C, Renn M, Tormo D, Morskaya SS, et al. 5'Triphosphate-siRNA: Turning Gene Silencing and Rig-I Activation Against Melanoma. Nat Med (2008) 14(11):1256-63. doi: 10.1038/nm.1887

81. Duewell P, Steger A, Lohr H, Bourhis H, Hoelz H, Kirchleitner SV, et al. RIG-I-Like Helicases Induce Immunogenic Cell Death of Pancreatic Cancer Cells and Sensitize Tumors Toward Killing by CD8(+) T Cells. Cell Death Differ (2014) 21(12):1825-37. doi: 10.1038/cdd.2014.96

82. Domankevich V, Efrati M, Schmidt M, Glikson E, Mansour F, Shai A, et al. RIG-1-Like Receptor Activation Synergizes With Intratumoral Alpha Radiation to Induce Pancreatic Tumor Rejection, Triple-Negative Breast Metastases Clearance, and Antitumor Immune Memory in Mice. Front Oncol (2020) 10:990. doi: 10.3389/fonc.2020.00990 
83. Kent A, Blander JM. Nod-Like Receptors: Key Molecular Switches in the Conundrum of Cancer. Front Immunol (2014) 5:185. doi: 10.3389/ fimmu.2014.00185

84. da Silva Correia J, Miranda Y, Austin-Brown N, Hsu J, Mathison J, Xiang R, et al. Nod1-Dependent Control of Tumor Growth. Proc Natl Acad Sci U S A (2006) 103(6):1840-5. doi: 10.1073/pnas.0509228103

85. Akramiene D, Kondrotas A, Didziapetriene J, Kevelaitis E. Effects of BetaGlucans on the Immune System. Med (Kaunas) (2007) 43(8):597-606.

86. Demir G, Klein HO, Mandel-Molinas N, Tuzuner N. Beta Glucan Induces Proliferation and Activation of Monocytes in Peripheral Blood of Patients With Advanced Breast Cancer. Int Immunopharmacol (2007) 7(1):113-6. doi: 10.1016/j.intimp.2006.08.011

87. Ostadrahimi A, Esfahani A, Asghari Jafarabadi M, Eivazi Ziaei J, Movassaghpourakbari A, Farrin N. Effect of Beta Glucan on Quality of Life in Women With Breast Cancer Undergoing Chemotherapy: A Randomized Double-Blind Placebo-Controlled Clinical Trial. Adv Pharm Bull (2014) 4(Suppl 1):471-7. doi: 10.5681/apb.2014.070

88. Liang M, Zhang P, Fu J. Up-Regulation of LOX-1 Expression by TNF-Alpha Promotes Trans-Endothelial Migration of MDA-MB-231 Breast Cancer Cells. Cancer Lett (2007) 258(1):31-7. doi: 10.1016/j.canlet.2007.08.003

89. Delneste Y, Magistrelli G, Gauchat J, Haeuw J, Aubry J, Nakamura K, et al. Involvement of LOX-1 in Dendritic Cell-Mediated Antigen CrossPresentation. Immunity (2002) 17(3):353-62. doi: 10.1016/s1074-7613(02) 00388-6

90. Oka K, Sawamura T, Kikuta K, Itokawa S, Kume N, Kita T, et al. Lectin-Like Oxidized Low-Density Lipoprotein Receptor 1 Mediates Phagocytosis of Aged/Apoptotic Cells in Endothelial Cells. Proc Natl Acad Sci U S A (1998) 95(16):9535-40. doi: 10.1073/pnas.95.16.9535

91. Joo H, Li D, Dullaers M, Kim TW, Duluc D, Upchurch K, et al. C-Type Lectin-Like Receptor LOX-1 Promotes Dendritic Cell-Mediated ClassSwitched B Cell Responses. Immunity (2014) 41(4):592-604. doi: 10.1016/ j.immuni.2014.09.009

92. Condamine T, Dominguez GA, Youn JI, Kossenkov AV, Mony S, AliceaTorres K, et al. Lectin-Type Oxidized LDL Receptor-1 Distinguishes Population of Human Polymorphonuclear Myeloid-Derived Suppressor Cells in Cancer Patients. Sci Immunol (2016) 1(2):aaf8943. doi: 10.1126/ sciimmunol.aaf8943

93. Chandra D, Quispe-Tintaya W, Jahangir A, Asafu-Adjei D, Ramos I, Sintim HO, et al. STING Ligand C-Di-GMP Improves Cancer Vaccination Against Metastatic Breast Cancer. Cancer Immunol Res (2014) 2(9):901-10. doi: 10.1158/2326-6066.CIR-13-0123

94. Weiss JM, Guerin MV, Regnier F, Renault G, Galy-Fauroux I, Vimeux L, et al. The STING Agonist DMXAA Triggers a Cooperation Between T Lymphocytes and Myeloid Cells That Leads to Tumor Regression. Oncoimmunology (2017) 6 (10):e1346765. doi: 10.1080/2162402X.2017.1346765

95. Wang Z, Celis E. STING Activator C-Di-GMP Enhances the Anti-Tumor Effects of Peptide Vaccines in Melanoma-Bearing Mice. Cancer Immunol Immunother (2015) 64(8):1057-66. doi: 10.1007/s00262-015-1713-5

96. Yan H, Chen W. The Promise and Challenges of Cyclic Dinucleotides as Molecular Adjuvants for Vaccine Development. Vaccines (Basel) (2021) 9 (8):917. doi: 10.3390/vaccines9080917

97. Motedayen Aval L, Pease JE, Sharma R, Pinato DJ. Challenges and Opportunities in the Clinical Development of STING Agonists for Cancer Immunotherapy. J Clin Med (2020) 9(10):3323. doi: 10.3390/jcm9103323
98. Foote JB, Kok M, Leatherman JM, Armstrong TD, Marcinkowski BC, Ojalvo LS, et al. A STING Agonist Given With OX40 Receptor and PD-L1 Modulators Primes Immunity and Reduces Tumor Growth in Tolerized Mice. Cancer Immunol Res (2017) 5(6):468-79. doi: 10.1158/23266066.CIR-16-0284

99. Le Naour J, Zitvogel L, Galluzzi L, Vacchelli E, Kroemer G. Trial Watch: STING Agonists in Cancer Therapy. Oncoimmunology (2020) 9(1):1777624. doi: 10.1080/2162402X.2020.1777624

100. Flood BA, Higgs EF, Li S, Luke JJ, Gajewski TF. STING Pathway Agonism as a Cancer Therapeutic. Immunol Rev (2019) 290(1):24-38. doi: 10.1111/ imr. 12765

101. Wang H, Hu S, Chen X, Shi H, Chen C, Sun L, et al. cGAS is Essential for the Antitumor Effect of Immune Checkpoint Blockade. Proc Natl Acad Sci U S A (2017) 114(7):1637-42. doi: 10.1073/pnas.1621363114

102. Benci JL, Xu B, Qiu Y, Wu TJ, Dada H, Twyman-Saint Victor C, et al. Tumor Interferon Signaling Regulates a Multigenic Resistance Program to Immune Checkpoint Blockade. Cell (2016) 1671540-1554(6):e1512. doi: 10.1016/ j.cell.2016.11.022

103. Luo M, Liu Z, Zhang X, Han C, Samandi LZ, Dong C, et al. Synergistic STING Activation by PC7A Nanovaccine and Ionizing Radiation Improves Cancer Immunotherapy. J Control Release (2019) 300:154-60. doi: 10.1016/ j.jconrel.2019.02.036

104. Wu J, Li S, Yang Y, Zhu S, Zhang M, Qiao Y, et al. TLR-Activated Plasmacytoid Dendritic Cells Inhibit Breast Cancer Cell Growth In Vitro and In Vivo. Oncotarget (2017) 8(7):11708-18. doi: 10.18632/ oncotarget.14315

105. Tarhini AA, Cherian J, Moschos SJ, Tawbi HA, Shuai Y, Gooding WE, et al. Safety and Efficacy of Combination Immunotherapy With Interferon Alfa-2b and Tremelimumab in Patients With Stage IV Melanoma. J Clin Oncol (2012) 30(3):322-8. doi: 10.1200/JCO.2011.37.5394

106. Crosby EJ, Wei J, Yang XY, Lei G, Wang T, Liu CX, et al. Complimentary Mechanisms of Dual Checkpoint Blockade Expand Unique T-Cell Repertoires and Activate Adaptive Anti-Tumor Immunity in TripleNegative Breast Tumors. Oncoimmunology (2018) 7(5):e1421891. doi: 10.1080/2162402X.2017.1421891

Conflict of Interest: Author YY is/was employed by Zenomics. Inc.

The remaining authors declare that the research was conducted in the absence of any commercial or financial relationships that could be construed as a potential conflict of interest.

Publisher's Note: All claims expressed in this article are solely those of the authors and do not necessarily represent those of their affiliated organizations, or those of the publisher, the editors and the reviewers. Any product that may be evaluated in this article, or claim that may be made by its manufacturer, is not guaranteed or endorsed by the publisher.

Copyright (c) $2021 \mathrm{Ye}, \mathrm{Xu}$, Chen, Liu and Cheng. This is an open-access article distributed under the terms of the Creative Commons Attribution License (CC BY). The use, distribution or reproduction in other forums is permitted, provided the original author(s) and the copyright owner(s) are credited and that the original publication in this journal is cited, in accordance with accepted academic practice. No use, distribution or reproduction is permitted which does not comply with these terms. 